\title{
PENDAMPINGAN ORANG TUA DALAM PEMBELAJARAN IPS DI MASA PANDEMI COVID-19 (DESA AYAMPUTIH KEC. BULUSPESANTREN KAB. KEBUMEN)
}

\author{
Tri Nur Ngaeni. Aisyah Nur Sayidatun Nisa ${ }^{\bowtie}$
}

Sosial Sciences Education Department, Faculty of Sosial Sciences, Universitas Negeri Semarang, Indonesia

\section{Info Artikel \\ Sejarah Artikel: \\ Disubmit Oktober 2020 \\ Direvisi Oktober 2020 \\ Diterima November 2020 \\ Keywords: \\ Mentoring; Parents; IPS \\ Learning; The Covid-19 \\ Pandemi}

\begin{abstract}
Abstrak
Pembelajaran jarak jauh (PJJ) merupakan salah satu kebijakan yang ditetapkan pemerintah di masa pandemi covid-19 ini. PJJ ini mengharuskan peserta didik untuk melakukan pembelajaran di rumah masing-masing melalui system daring. Dalam kegiatan PJJ orang tua kini memiliki peran menjadi guru bagi anak-anakanya. Peran ini di peroleh sebab orang tua dalam keluarga memiliki fungsi memberikan edukasi bagi anggota keluarganya. Penelitian ini bertujuan untuk mengetahui bagaimana pendampingan orang tua dalam pembelajaran IPS di masa pandemi covid-19 di Desa Ayamputih, Kecamatan Buluspesantren, Kabupaten Kebumen. Metode penelitian yang digunakan adalah metode kualitatif. Metode kualitatif adalah metode yang lebih menekankan pada aspek pemahaman secara mendalam terhadap suatu masalah teknik pengembilan data yang digunakan oleh peneliti adalah dengan melakukan wawancara kepada informan. Hasil penelitian menunjukan bahwa : (1) pelaksanaan pembelajaran yang dilakukan peserta didik dilakukan sepenuhnya secara daring. (2) pendampingan orang tua dalam pembelajaran IPS hanya dilakukan ketika anak merasa kesulitan dalam pengerjaan tugas yang diberikan oleh guru.
\end{abstract}

Abstract

Distance learning (PJJ) is one of the policies set by the government during the Covid-19 pandemic. This PJJ requires students to carry out learning at home through an online system. In PJJ activities, parents now have the role of being a teacher for their children. This role is obtained because parents in the family have the function of providing education for family members. This study aims to find out how parental assistance is in IPS learning during the Covid-19 pandemic in Ayamputih village, Buluspesantren sub-district, Kebumen district. The research method used is a qualitative method. Qualitative method is a method that emphasizes in-depth understanding aspects of a problem data collection technique used by researchers is by conducting interviews with informants. The results showed that: (1) the implementation of learning carried out by students was carried out entirely online. (2) parental assistance in IPS learning is only done when the child finds it difficult to do the assignments given by the teacher.

(C) 2020 Universitas Negeri Semarang

ISSN 2252-7133

$凶$ Alamat korespondensi:

E-ISSN 2548-4648 
E-mail: trinurngaeni@students.unnes.ac.id;

aisyah8816@mail.unnes.ac.id

\section{PENDAHULUAN}

Adanya coronavirus disease 2019 (Covid19) telah menjadi pandemi global yang melanda hamper seluruh dunia. Hal ini pula yang telah menyebabkan banyak perubahan diberbagai bidang, tak terkecuali bidang pendidikan. Pendidikan sendiri merupakan suatu upaya untuk meningkatkan sumber daya manusia dan harus dilakukan oleh setiap individu. Di Indonesia sendiri, sudah banyak kebijakan yang dikeluarkan oleh pemerintah sebagai wujud pencegahan penyebaran virus corona.

Dalan surat edaran Mendikbud No.4 Tahun 2020 Kementrian Pendidikan dan Kebudayaan (Kemendikbud) memberikan arahan terkait perubahan system pembelajaran di sekolah menjadi system pembelajaran jarak jauh (PJJ). Arahan ini ditunjukan untuk seluruh satuan pendidikan yang ada di Indonesia, mulai dari PAUD samapai Perguruan Tinggi. Pembelajaran jarak jauh ini dimaksudkan agar lembaga pendidikan tidak menjadi claster baru penyebaran virus corona. Penerapan pembelajaran jarak jauh ialah pembelajaran scara daring dengan memanfaatkan teknologi informasi yang berkembang saat ini.

Teknologi informasi merupakan dari perkembangan ilmu pengetahuan. Teknologi informasi dalam dunia pendidikan mampu menjadi alat penyampai informasi dari guru kepada peserta didik. Dalam situasi pandemi seperti sekarang, teknologi informasi mempunyai peran sebagai penyampai gagasan atau ide, pendapat, materi pembelajaran dan tempat dimana kegiatan pembelajaran dilakukan.

Kegiatan pembelajaran yang dilakukan oleh peserta didik selama pandemi telah membuat perserta didik harus mengalami adaptasi kebiasaan baru dengan suasana belajar yang berbeda dari biasanya. Sebelum adalanya pandemi ini peserta didik terbiasa melakukan pembelajaran disekolah dengan suasana yang tenang, dikelilingi oleh banyak teman dan juga diajarkan oleh guru secara langsung. Namun, pada masa pandemi seperti sekarang ini, peserta didik melakukan kegiatan pembelajaran dirumah secara daring melalui teknologi informasi yang meleka miliki, seperti gawai, laptop, notebook, computer dan lain sebagainya.

Tak hanya peserta didik yang harus beradaptasi guru dan orang tua juga harus beradaptasi dengan perubahan yang ada. Kini selain menjadi orang tua bagi anak, peran orang tua pun bertambah menjadi seorang guru dalam mendampingi anak belajar secara daring dirumah. Menurut Lestari (dalam Kurniati, dkk., 2020) menyatakan bahwa keluarga dilihat dari fungsinya yakni memiliki tugas dan fungsi perawatan, dukungan emosi dan materi, serta pemenuhan peranan tertentu. Dalam hal ini orang tua dituntut untk dapat mengerti setiap mata pelajaran anak yang diajarkan di sekolahnya.

Mata pelajaran ilmu pengetahuan sosial (IPS) merupakan salah satu mata palajaran yang harus dikuasai oleh orang tua. Dalam mata pelajaran IPS terdapat berbagai rumpun ilmu sosial yang dijadikan menjadi satu kesatuan yang terpadu. Dalam jenjang pendidikan SMP mata pelajaran IPS mencakup 4 rumpun ilmu, yaitu ekonomi, geografi, sejarah dan sosiologi.

Menurut soemantri (dalam Darsono dkk., 2017) pendidikan IPS adalah suatu penyederhanaan dari disiplin ilmu-ilmu sosial, ideology negara dan disiplin ilmu lainnya serta masalah-masalah sosial terkait yang diorganisasikan dan disajikan secara ilmiah dan psikologis untuk tujuan pendidikan pada tingkat pendidikan dasar dan menengah.

Menurut Ellis (dalam Manik dkk., 2016) bahwa tujuan pembelajaran IPS dalah sosial studies is designed to helps children explain their world. By organization he basically meant the ability to understand and classify things with respect to how they work. Adaptation refers to the process of accommodating one self to one's environment. A child who enters school has already adapted considerably to 
the environment throught speech, dress, rules at home, and so forth but school is designed to expand such adaptation greatly throught formatl learning processes, sosial, emotional, and physical.

Sedangkan, menurut Nursid (dalam surahman dkk., 2017) mata pelajaran IPS bertujuan mengembangkan potensi peserta didik agar peka terhadap masalah sosial yang terjadi dimasyarakat, memiliki sikap mental positif terhadap perbaikan segala ketimpangan yang terjadi dan terampil mengatasi setiap masalah yang terjadi sehari-hari baik yang menimpa dirinya sendiri maupun yang menimpa kehidupan masyarakat.

Berdasarkan uraian tujuan dari penelitian ini adalah untuk mengetahui bagaimana pendampingan orang tua dalam pembelajaran IPS di masa pandemi Covid-19 yang dilakukan di desa Ayamputih, Kec. Buluspesantren, Kab. Kebumen.

\section{METODE}

Pendekatan yang digunakan dalam penelitian ini ialah melalui pendekatan kualitatif. Pendekatan kulitatif ialah pendekatan yang temuan-temuannya tidak diperoleh melalui prosedur statistic atau bentuk hitungan lainnya. Menurut Kirkl dan Miller (dalam Moleong, 2011) penelitian kualitatif adalah tradisi tertentu dalam ilmu pengetahuan sosial yang secara fundamental bergantung dari pengamatan pada manusia baik dalam kawasannya maupun dalam peristilahannya.

Latar penelitian ini dilakukan di Desa Ayamputih, Kec. Buluspesantren, Kab. Kebumen dengan fokus penelitian pada bagaimana proses pendampingan orang tua kepada anak dalam pembelajaran IPS di masa pandemi Covid-19 seperti sekarang ini.

Sumber data yang dimiliki oleh peneliti berasal dari informan yang terdiri dari orang tua dan peserta didik dan dokumen-dokumen yang relevan dengan penelitian ini. Teknik pengumpulan data yang digunakan ialah melalui wawancara langsung secara mendalam terhadap informan dengan informan dan mencari dokumen.

\section{PEMBAHASAN}

\section{Pelaksanaan Pembelajaran IPS di Masa Pandemi Covid-19}

Di masa pandemi seperti sekarang ini, perubahan yang terjadi di bidang pendidikan telah membuat banyak perubahan. Perubahan yang terjadi bukan tanpa sebab dan tak ada tujuannya. Kegiatan pembelajaran yang biasanya dilakukan di sekolah berubah menjadi sepenuhnya dilakukan secara daring. Kegiatan pembelajaran daring ini dilakukan melalui media sosial. Menurut Damian Ryan dan Jones (dalam Abiddin) dalam bukunya yang berjudul Understanding Digital Marketing : Marketing Strategies For Engaging The Digital Generation menjelaskan bahwa media sosial adalah software berbasis web yang memungkinkan pengguna untuk daring berbagi secara online, berdikusi, dan berpartisipasi dalam segala bentuk interaks sosial. Media sosial yang sering digunakan oleh peserta didik dalam melakukan kegiatan pembelajaran IPS ialah media sosial Whatsapp. Whatsapp merupakan media komunikasi yang digunakan menyampaikan pesan dan berkomunikasi baik perorangan maupun kelompok. Terdapat banyak fitur-fitur dalam Whatsapp yang dapat digunakan tak hanya sebatas sebagai media komunikasi namun juga media pembelajaran. Dalam situasi pandemi sepeti sekarang Whatsapp Grup merupakan salah satu media yang banyak digunakan sebagai sarana berinteraksi antara guru dengan peserta didik. Selain, menggunakan Whatsapp dalam melakukan kegiatan pembelajaran IPS guru juga menggunakan platform kelas online Google Classroom untuk dapat berinterkasi dengan siswa. Namun, dari kedua media yang digunakan ini, guru lebih sering menggunakan Whatsapp Grup dari pada Google Classroom.

Selain, melakukan pembelajaran yang sepenuhnya daring, sebenarnya siswa juga melakukan kegiatan pengumpulan tugas ke sekolah pada saat guru meminta pengumpulan tugas individual secara langsung. Waktu pengumpulan tugas ini pun hanya dilakukan sesekali sebab agar tetap dapat menjaga penyebaran virus corona. Pengumpulan tugas 
yang dilakukan oleh peserta didik dilakuakn secara individual dengan tetap menjalakan protokol kesehatan dan proses pengumpulan tugasnya hanya dilakukan dengan hanya meletakan tugas yang sudah dikerjakan diatas meja guru setelah itu langsung kembali pulang ke rumah masing-masing.

Sumber belajar yang digunakan peserta didik untuk melakukan pembelajaran daring agaknya tidak jauh berbeda dari pembelajaran offline di kelas. Mclsaac dan Gunawardena ( dalam Supriadi, 2015) menjelaskan bahwa sumber belajar yang dapat dimanfaatkan untuk kebutuhan pembelajaran sangat beraneka ragam jenis dan bentuknya. Dalam hal ini sumber belajar yang digunakan peserta didik, berupa buku IPS terpadu, buku LKS IPS terpadu, Youtube dan Google. Peserta didik mengakui penggunaan sumber belajar buku digunakan sebagai bahan mencari jawaban ketika guru mengadakan kuis melalui Whatsapp Grup. Kemudian, Youtube sebagai sumber pembelajaran digunakan sebagai alternative untuk menjelaskan materi pembelajaran IPS yang mana dalam pembelajaran daring seperti sekarang ini guru mengalami banyak kesulitan sebab tidak bias menjelaskan materi pembelajaran IPS secara langsung.

Dalam pelaksanaan pembelajaran IPS secara daring yang dilakukan peserta didik di Desa Ayamputih, Kec. Buluspesantren, Kab. Kebumen peserta didik merasa banyak mengalami hambatan. Beberapa hambatan yang dialami oleh peserta didik ialah keterbatasan waktu dalam proses pembelajaran daring, kesulitan peserta didik dalam memahami materi pembelajaran yang disampaikan oleh guru, kendala jaringan yang terkadang kurang stabildan suasana rumah yang terkadang kurang kondusif untuk belajar. Selain itu juga, peserta didik merasa sangat bosan dalam pembelajaran IPS yang dilakukan oleh guru. Menurut Nurkholis (dalam Kurniati, dkk., 2020) dampak sari situasi pandemi Covid-19 pada peserta didik adalah kejenuhan dan kebosanan.
Dari adanya hambatan-hambatan yang ada peserta didik sangat berharap apabila guru melakukan perubahan media pembelajaran yang hanya menggunakan Whatsapp grup, tetapi juga menggunakan media pembelajaran berbasis video conference, seperti zoom, google meet, skype atau aplikasi lainnya. Peserta didik juga berharap guru dapat menjelasakan materi pembelajaran IPS secara langsung melalui video agar peserta didik dapat lebih mudah memahami materi pembelajaran IPS yang menurut mereka mata pelajaran IPS itu sangat penting.

Namun, dibalik hambatan yang ada, pihak sekolah senantiasa terus membantu peserta didik dalam melakukan kegiatan pembelajaran di rumah. Bentuk-bentuk bantuan yang diberikan oleh pihak sekolah, berupa pinjaman buku paket IPS Terpadu dan paket data internet. Peminjaman ini diberikan agar siswa dapat terbantu dalam memahami materi pembelajaran yang disampaikan oleh guru. Paket data internet yang juga diberikan sekolah bertujuan untuk membantu meringakan beban pembelian kuota internet untuk kegiatan pembelajaran.

\section{Pendampingan Orang Tua dalam Pembelajaran IPS di Masa Pandemi Covid-19}

Selama pandemi covid-19 orang tua dikaruniai peran lain, yaitu sebagai guru bagi anaknya. Peran ini tidak semerta-merta dating begitu saja. Adanya pandemi dan kebijakan pemerintah yang mengharuskan seluruh kegiatan pembelajaran di sekolah beralih menjadi pembelajaran jarak jauh (PJJ) serta mencegah penyebaran virus corona di lembaga pendidikan telah membuat hal ini terjadi. Menurut Mattewakkang (dalam Kurniati dkk., 2020) dalam proses pembelajaran di rumah diharapkan guru serta orang tua dapat mewujudkan pendidikan tidak hanya berfokus pada pencapaian akademik atau kognitifnya saja tetapi dapat mewujudkan pendidikan yang bermakna, dibutuhkan saling pengertian dari pemerintah, sekolah serta masyarakat dan kegita elemen tersebut harus saling bersinergi. 
Adanya sinergi antar komponen pendidikan yang baik dan kuat akan menciptakan suatu suasana baru dengan kegiatan pembelajaran yang sesuai dengan situasi dan kondisi yang ada. Posisi orang tua dalam pendidikan anak dirumah harus ditekankan lebih kepada teman belajar yang membantu anak saat kegiatan pembelajaran. Berdasarkan hasil wawancara yang peneliti lakukan di Desa Ayamputih, Kec. Buluspesantren, Kab. Kebumen pendampingan orang tua dalam proses pembelajaran IPS yang dilakukan peserta didik hanya dilakukan secara tidak menentu. Tidak menentu ini maksudnya dilakukan hanya ketika orang tua sedang tidak sibuk dengan pekerjaan rumah dan pekerjaanpekerjaan lain yang harus dilakukan oleh orang tua.

Dalam proses pendampingan ini, orang tua membantu anak saat anak merasa kesulitan dalam mengerjakan tugas yang diberikan oleh guru. Orang tua juga membantu siswa dalam memahami materi pembelajarn yang guru sampaikan. Dalam hal peranan orang tua dirumah hal tersebut sebenarnya sudah cukup bagus, namun hanya saja tidak dilakukan setiap anak melakukan kegiatan pembelajaran dikarenakan orang tua juga memiliki pekerjaan lain, seperti bekerja, mengurus rumah, mengurus hewan ternak, dan lain sebagainya. Namun, kurang mengetahuinya akan adanya tujuan pendidikan dalam 3 ranah, yaitu kognitif, afektif, dan psikomotorik membuat hal ini menjadi kurang optimal.

Perlunya komunikasi dan koordinasi yang baik pada semua komponen pendidikan sangat diperlukan guna meningkatkan kefektifan dan optimalisasi kegiatan pembelajaran di rumah. Hal ini dilakukan juga agar anak tidak merasa bosan dan jenuh dengan kegiatan pembelajaran yang dilakukan oleh guru. Selain itu pula, orang tua juga harusnya mampu memberika movitasi atau dorongan agar anak dalam belajar menjadi lebih bersemangat. Menurut Yuliarti (dalam Kurniati dkk., 2020) pada dasarnya anak memiliki motivasi untuk melakukan suatu hal, apabila ia mendapatkan sebuah dorongan dari orang-orang terdekat seperti orang tua.

\section{SIMPULAN}

Masa pandemi Covid-19 merupakan masa-masa sulit bukan untuk mereka saja yang terinfeksi virusnya, namun juga untuk semua orang yang ada di muka bumi ini. Pandemi Covid-19 yang sudah melanda Indonesia hampir 8 bulan ini telah membuat banyak perubahan diberbagai bidang, salah satunya pendidikan. Pendidikan merupakan salah satu komponen penting dalam peningakatan sumber daya manusia.

Salah satu kebijakan dalam dunia pendidikan yang diberlakukan di masa pandemi ini adalah melakukan pembelajaran Jarak Jauh (PJJ). Dengan adanya kebijakan ini seluruh satuan pendidikan yang ada di Indonesia menghimbau agar peserta didik melakukan pembelajaran di rumah dengan system daring. Dengan adanya pembelajaran ini orang tua di rumah menjadi memiliki peran sebagai guru bagi anak-anaknya dalam proses pembelajaran di rumah. Pendampingan orang tua dalam pembelajarn IPS bagi peserta didik merupakan salah satu peran yang harus dilakukan orang tua. Namun, realitanya pendampingan yang dilakukan orang tua dalam kegiatan pembelajarn IPS peserta didik belum dilakukan secara optimal karena kesibukan lain yang dimiliki oleh orang tua dan kurang pahamnya orang tua akan tujuan pendidikan yang meliputi 3 ranah, kognitif, afektif, dan psikomotorik. Diperlukannya komunikasi dan koordinasi yang baik antar semua komponen dalam mendukung dan mengoptimalisasikan kegiatan pembelajaran IPS di rumah selama pandemi covid-19.

\section{DAFTAR PUSTAKA}

Abiddin, Zainal. Pemanfaatan Media Sosial sebagai Ruang Belajar Siber Pada Pendidikan di Era Digital. Jakarta Pusat : Program Paket A Setara SD PKBM Al Ishlah 
Darsono dkk., 2017. Sumber Belajar Penunjang PLPG 2017 Kompetensi Profesional Mata Pelajaran : Guru Kelas SD. Kementerian Pendidikan dan Kebudayaan Direktorat Jenderal Guru dan Tenaga Pendidik

Gunawan, Imam. Metode Penelitian Kualitatif. Universitas Negeri Malang

Kuniati, Euis dkk., 2020. Anailisis Peran Orang Tua dalam Menghadapi Anak di Masa Pandemi Covid-19. Jurnal Obsesi : Jurnal Pendidikan Anak Usia Dini, Vol 5, Issue 1 (2021) 241-256

Manik, Kardi ddk., 2016. Penerapan Model, Two Stay Two Stray Berbantuan Multimedia untuk Meningkatkan Aktivtas dan Hasil Belajar. Jurnal Harmoni Sosial : Jurnal Pendidikan Ips, Vol 3, No.1, Maret 2016 (36-39)

Moleong, Lexy. 2011. Metodologi penelitian Kualitatif. Bandung: Rosda

Surahman, Edy dkk, . 2017. Peran Guru Ips sebagai Pendidik dan Pengajar dalam Meningkatkan Sikap Sosial dan Tanggung Jawab Sosial Siswa SMP. Jurnal Harmoni Sosial : Jurnal Pendidikan Ips Vol 4, No. 1, Maret 2017 (1-13). 